\title{
Archiwum i obraz: fragmenty historii traumatycznej według H.G. Adlera
}

Dorota Głowacka

TEKSTY DRUGIE 2016, NR 5, S. 217-239

DOI: $10.18318 /$ td.2016.5.15

\section{Autor powieści w roli apokaliptycznego}

\section{Anioła Historii}

W znanym eseju Waltera Benjamina, zatytułowanym Tezy historiozoficzne (O pojęciu historii) [Über den Begriff der Geschichte], pojawia się sławny dziś opis Anioła Historii:

Oczy szeroko rozwarte, usta otwarte, skrzydła rozpięte. Tak musi wyglądać anioł historii. Zwrócił oblicze ku przeszłości. Gdzie nam ukazuje się łańcuch zdarzeń, on widzi jedną wieczną katastrofę, która nieustannie piętrzy ruiny na ruinach i ciska mu pod stopy. Chciałby zatrzymać się, zbudzić umarłych i złączyć to, co rozbite. Ale od raju wieje wicher, który napiera na skrzydła i jest tak silny, że anioł nie może ich złożyć. Ten wicher pędzi go niepowstrzymanie w przyszłość, do której jest zwrócony plecami, podczas gdy przed nim rośnie stos ruin. ${ }^{1}$

1 W. Benjamin Tezy historiozoficzne (O pojęciu historii) [Über den Begriff der Geschichte], w: Twórca jako wytwórca, wyb. H. Orłowski, przeł. J. Sikorski, Wydawnictwo Poznańskie, Poznań 1975.

\section{Dorota}

Głowacka - profesor nauk humanistycznych, wykładowczyni na University of King's

College w Kanadzie. Współredaktorka Between Ethics and Aesthetics (2002) i Imaginary Neighbors: Mediating Polish-Jewish Relations after the Holocaust (2007) oraz autorka Disappearing Traces: Holocaust Testimonials, Ethics and Aesthetics (2012). Opublikowała szereg artykułów w dziedzinie badań nad Zagładą, filozofii kontynentalnej, teorii genderowych i postkolonialnych. Kontakt: glowacka@ dal.ca 
Benjamin ukończył ostateczną wersję Tez w styczniu 1940 roku, niedługo przed tym, gdy w geście rozpaczy odebrał sobie życie podczas nieudanej próby przekroczenia granicy francusko-hiszpańskiej. Pisarz wyobraża sobie całokształt historii jako panoramę ruin, omiataną wzrokiem Anioła z rozpostartymi wichurą dziejów skrzydłami, bezradnego wobec piętrzących się zgliszczy. A więc oddaje on pamięć minionych wydarzeń za pomocą ekspresyjnego obrazu: przemieniona w stosy gruzu historia to ogromny, zamarły spektakl. Benjamin zaczerpnął to porównanie z obrazu Angelus Novus (1916) pędzla niemiecko-szwajcarskiego artysty Paula Klee, który zakupił w 1921 roku i powiesił w swoim gabinecie, by służył mu jako „punkt pozwalający skupić myśli". Obraz towarzyszył pisarzowi na wygnaniu w Paryżu, a gdy do stolicy Francji wkroczyli Niemcy, powierzył go wraz ze swymi rękopisami przyjacielowi Georges'owi Battaille'owi, który w tym czasie pracował jako bibliotekarz w paryskiej Biliothéque Nationale.

W tym samym czasie czeski pisarz H.G. Adler, członek mówiącej po niemiecku żydowskiej mniejszości narodowej, usiłuje przetrwać w Pradze w warunkach pogarszającego się z dnia na dzień „stanu wyjątkowego”, o którym ostrzegał w Tezach Benjamin. Wkrótce zostanie wysłany z Pragi do getta w Terezinie, a następnie do Auschwitz. Wyzwolony przez armię angielską z obozu w Buchenwaldzie, przeżyje wojnę jako jedyny z całej swej rodziny.

Hans Günther Adler urodził się w Pradze w 1910 roku, w świeckiej rodzinie żydowskiej. Przed wojną studiował filozofię, literaturę i muzykologię na niemieckojęzycznym uniwersytecie praskim i obracał się w kręgach znanych pisarzy i intelektualistów. Tuż po wojnie pracował w Praskim Muzeum Żydowskim, przeznaczonym przez hitlerowców na "muzeum wymarłej rasy”, w którym miała znaleźć się kolekcja przedmiotów zrabowanych wywiezionym do obozów Żydom. W obawie przed wprowadzeniem w Czechosłowacji reżimu komunistycznego Adler wyjechał do Anglii w 1947 roku, gdzie mieszkał - jak twierdził - „na wygnaniu" aż do śmierci w 1988 roku. Pisanie prac na temat Zagłady, historii i kultury europejskich Żydów uważał za swoje życiowe posłannictwo.

Do niedawna twórczość Adlera znana była jedynie niektórym badaczom Zagłady z monografii zatytułowanej Theresienstadt 1941-1945. Das Antlitz einer Zwangsgemeinschaft [Terezin 1941-1945: Oblicze społeczności znajdującej się pod przymusem], którą autor pisał w latach 1945-1948 i wydał w roku 1955 jako jedną z pierwszych opublikowanych prac na temat obozów hitlerowskich².

2 Praca otrzymała prestiżową niemiecką nagrodę literacką Leo Becka w 1958 roku, choć wkrótce potem popadła w zapomnienie. 
Adler zaczął robić notatki do pracy natychmiast po przybyciu do Terezina, a gdy dowiedział się, że jego nazwisko znajduje się na liście następnego transportu do Auschwitz, pozostawił je pod opieką Leo Baecka, słynnego berlińskiego rabina, również więzionego w Terezinie, który zdołał przechować obszerne już wówczas archiwum zapisków. Dodajmy jako ciekawostkę, że Adler publikował swoje prace jako H.G. Adler, ponieważ szef praskiego gestapo, odpowiedzialny również za projekt „upiększania” getta w Terezinie, nazywał się Hans Günther.

Natomiast niewiele wiedzieliśmy o Adlerze jako autorze kilku tomów wierszy, z których ponad sto napisał w Terezinie i przechowywał pod groźbą śmierci, czy o Adlerze - powieściopisarzu, którego wojenna trylogia Panorama. Roman in zehn Bildern [Fotoplastykon: powieść w dziesięciu obrazach], Eine Reise [Podróż] i Die unsichtbare [Niewidzialna ściana] stanowiły jedną z pierwszych prób literackiej transpozycji doświadczeń obozowych. Zwłaszcza Podróż okazała się zbyt idiosynkratyczna, a nawet obrazoburcza w atmosferze wczesnych lat powojennych. Szef prestiżowego wydawnictwa berlińskiego Suhrkamp Verlag zawyrokował: „dopóki żyję, książka ta nie ukaże się w Niemczech!"3. Została ona również ostro skrytykowana przez Theodora Adorna, z którym od 1950 roku pisarz prowadził początkowo przyjazną korespondencję ze względu na wspólne zainteresowania socjologią i muzykologią ${ }^{4}$ O Podróży pozytywnie wypowiadali się znani intelektualiści niemieccy, tacy jak Elias Canetti i Heinrich Böll. Jednak dopiero po śmierci pisarza jego prace doczekały się namiastki uznania, a nawet pochlebnych porównań z innym pisarzem z tego samego środowiska - Franzem Kafką. Przyczynił się do czego częściowo fakt, że jednym z jego entuzjastycznych czytelników okazał się znany niemiecki pisarz W.G. Sebald, który umieścił cytat z książki Adlera o Terezinie w wielokrotnie nagradzanej powieści Austerlitz, a także fotografię jednej ze stronic.

Katastrofa, której Adler był naocznym świadkiem, przemieniła ostrzeżenie Benjamina przed zagrożeniem ze strony faszyzmu w proroctwo. Przypomnijmy, że w Tezach Benjamin krytykuje tradycyjną historiografię, gdyż zawsze obiera ona punkt widzenia zwycięzcy i staje po stronie wielkich budowniczych cywilizacji, pozwalając reszcie ludzkości popaść w niepamięć.

3 J. Creet, S.R. Horowitz A. Bojadzija-Dan Introduction: Encountering H.G. Adler, w: H. G. Adler: Life Literature, Legacy, Evanston, Illinois 2016, s. 9.

4 Korespondencja dotyczyła książki Adorna Philosophy of Modern Music oraz eseju The Sociology of Concentration Camps. Adler był autorem przychylnej recenzji pracy, natomiast Adorno wypowiadał się pozytywnie o studium o Terezinie. 
Niemiecki myśliciel opowiada się za wizją historycyzmu materialistycznego, połączonego ze "słabą" ideą mesjańską, którego zadaniem jest udokumentowanie barbarzyńskich czynów, skrywających się pod osłoną cywilizacji. Proponuję odczytanie prac Adlera w świetle tez Benjamina, uwypuklając wizualny element Benjaminowskiej wizji historii. W następstwie Zagłady Anioł Historii objawia nam się jako postać badacza historii, który jest jednocześnie jej naznaczonym traumą uczestnikiem. Zdaje on sobie sprawę ze swego posłannictwa, lecz zastygł w obliczu gigantycznego widowiska, które zredukowało historię do stosu trupów. Nie jest w stanie odwrócić wzroku, oderwać oczu od strasznego widoku.

W krótkim wierszu Ein Auge, Offen [Oko, otwarte] ocalony z katastrofy poeta Paul Celan tak uchwycił zgrozę i cierpienie zawarte w porażonym traumą wzroku: „Pulsująca bólem głębia gałki ocznej: / powieka / nie jest przeszkodą"5. Przywołuję tu Celana, ponieważ zarówno ten wybitny poeta jak i H.G. Adler próbowali zmierzyć się z wyzwaniem rzuconym przez Zagładę problematyce przedstawialności. Natychmiast po zakończeniu wojny obaj podjęli się zadania niesienia świadectwa w ojczystym języku niemieckim, świadomi, że jest to również język ich oprawców, język, który przeszedł przez „tysiąc ciemności mowy niosącej śmierć"6. Obaj dość wcześnie zdali sobie sprawę, że tradycyjne sposoby mierzenia się z historią nie zdołają unieść epistemologicznego i afektywnego ciężaru wojennych zniszczeń. Jak wynika z ich odmiennej pod wieloma względami twórczości, byli też przeświadczeni, że poszukiwanie nowych środków wyrazu nieuchronnie prowadzi do refleksji nad wagą, istotą i skutecznością poetyckiego obrazu w przekazywaniu traumatycznego doświadczenia. Jednak, w przeciwieństwie do Celana, Adler kwestionuje dogmat, wywodzący się po części z wpływowego stwierdzenia Adorna, sformułowanego w 1949 roku w eseju Kulturkritik und Geselschaft, że "Auschwitz" opiera się estetycznemu przetworzeniu i władzy wyobraźni. Pasjonuje go bowiem pytanie o możliwości empatycznej wyobraźni, a nie o jej ograniczenia, jeśli chodzi o przekazywanie doświadczenia, które uchyla się zarówno percepcji zmysłowej, jak i logicznej analizie.

Zapewne to nie przypadek, że Benjaminowska "słaba mesjanistyczna" wizja historii, którą przedstawił w Tezach, stała się obiektem surowej krytyki ze

5 P. Celan Ein Auge, Offen, w: Selected Poems and Prose of Paul Celan, edycja dwujęzyczna, przeł. J. Felstiner, W.W. Norton, New York 2001, s. 116-117.

6 P. Celan Ansprache anlässlich der Entgegennahme des Literaturpreises der Freien Hansestadt Bremen (1958), w: Selected Poems and Prose of Paul Celan, s. 395, wyróżnienie - D.G. 
strony Adorna i Horkheimera, którzy oskarżyli go o teologiczne i poetyzujące deformowanie myśli marksistowskiej. W latach 50. Adorno zwrócił swe polemiczne ostrze m.in. przeciwko Adlerowi i jego idiosynkretycznej interpretacji historii jako zastygłego obrazu, który przyszło świadkowi odkupić. Niemiecki socjolog potępiał wszelkie estetyzujące świadectwa Zagłady, takie jak wiersz Celana Todesfuge czy kompozycję Arnolda Schönberga Ocalaty z Warszawy, natomiast proponował negatywną, całkowicie wyzutą z obrazów estetykę Samuela Becketta jako jedyną sensowną odpowiedź na Zagładę. W ocenie prac Becketta ujawnia się więc niezgodność poglądów dotyczących roli estetyki "po Auschwitz" między Adlerem i Beckettem: znana była wypowiedź Adlera, że gdyby Beckett przeszedł przez obozy hitlerowskie, z całą pewnością pisałby „inaczej, bardziej pozytywnie”, którą Adorno zgromił w Dialektyce negatywnej". W rozumieniu Adlera, kluczowym zadaniem pisarza czy artysty jest radykalne przemyślenie roli obrazu i obrazowania w odniesieniu do Zagłady, a nie zaś jego odrzucenie w imię tezy o nieprzedstawialności.

\section{Podróż do etycznych źródeł obrazu}

Podróż, napisana w latach 1950-1951 i wydana po raz pierwszy w 1955 roku, to niekonwencjonalna alegoria, opisująca tragiczne przejścia, a następnie śmierć najbliższych członków rodziny pisarza, od początku do końca sprawia wrażenie sennego koszmaru. Ciemne, oniryczne sekwencje opisują wysiedlenie rodziny Adlera (powieściowego Paula) z Pragi (miejscowości Stupart) do Terezina (Ruhenthal) w lutym 1942 roku, wraz z żoną, Gertrudą Adler-Klepetar (która pojawia się w powieści jako Zerlina, siostra Paula) i teściami (Leopoldem i Karoliną Lustig), a następnie śmierć teścia w Terezinie, wywózkę pozostałych członków rodziny do Auschwitz-Birkenau w październiku 1944 roku, gdzie żona Adlera wybrała śmierć w komorze gazowej u boku swojej matki, a na koniec wyzwolenie.

Powieść otwiera krótka sekwencja zatytułowana Przepowiednia, w której projekt upamiętnienia odbywa się w formie spektaklu teatralnego; zmarli wyłaniają się zza kurtyny i oznajmiają: „Nie, nie zginęliśmy [...]. Ale ustawiliśmy się na scenie"». Pierwsza odsłona powieści jest przenośnią o charakterze wizualnym. Retrospektywny opis wędrówek bohatera rozpoczyna się

7 Zob. Th.W. Adorno Dialektyka negatywna, przeł. K. Krzemieniowa, S. Krzemień-Ojak, red. N. Szancer, PWN, Warszawa 1986), s. 516.

8 H.G. Adler The Journey. A Novel, przeł. z niemieckiego P. Filkins, New York 2008, s. 5-6. 
podniesieniem kurtyny, a padające ze sceny światło rozprasza mrok panujący na widowni. W porównaniu z Fotoplastykonem, którego przestrzeń narracyjna była wyznaczona wyłącznie serią obrazów, metaforyczne sensorium Podróży jest wzbogacone również o element muzyczny. Pierwotny tytuł powieści, Eine Raise (Eine Ballade), usunięty przez autora na życzenie wydawcy, nawiązuje bezpośrednio do formy muzycznej, która była bardzo popularna w dobie niemieckiego romantyzmu. Nic dziwnego, że po ukazaniu się powieści w 1955 roku, niemiecki krytyk literacki Heimito von Doderer potępił jej muzyczno-malarską estetykę, oskarżając Adlera, że „przetworzył ogrom horroru na pieśń”. Podobnie jak wydawca powieści, von Doderer nie dostrzega ani gorzkiego, ironicznego wydźwięku Adlerowskiego odniesienia do romantycznej konwencji ballady, ani faktu, że linearną metaforę podróży zakłóca atonalna muzyczna synkopa, która akompaniuje przytłaczającym onirycznym obrazom.

Odwołująca się do rozmaitych form artystycznych, Podróż stanowi prekursorską refleksję na temat zarówno epistemologicznej, jak i etycznej roli sztuki wobec Zagłady. Synkretyczne połączenie tekstu, obrazu i formy muzycznej w celu przekazania treści o charakterze traumatycznym przywodzi na myśl niezwykłe dzieło zatytułowane Leben? Oder Theater? Ein Singspiel [Życie? Czy teatr? Pieśń-sztuka] niemieckiej artystki pochodzenia żydowskiego, Charlotte Salomon, zamordowanej w Auschwitz w 1943 roku $^{10}$. Zawiera ono ponad tysiąc rysunków będących wizualnym zapisem wydarzeń z życia artystki, począwszy od dzieciństwa naznaczonego samobójczą śmiercią bliskich członków rodziny, przez rozwój talentu artystycznego, pierwszą miłość, a następnie życie w ukryciu podczas okupacji. Plansze są opatrzone podpisami, stanowiącymi libretto, do którego dołączona jest partytura. Uderza również podobieństwo tonu dzieł Adlera i Salomon - pobrzmiewają nutą szczególnej lirycznej ironii, która najwyraźniej wydała się wcześniejszym odbiorcom nie do przyjęcia. Nic więc dziwnego, że obie te prace - wybitne i niekonwencjonalne świadectwa Zagłady - musiały czekać wiele lat, zanim znaleźli się odbiorcy, którzy byli w stanie docenić ich nowatorstwo i poszukiwawczą pasję ich autorów.

Pierwszy akt Adlerowskiego teatrum mundis, rozdział zatytułowany Opowieść, zapowiada nieszczęście czyhające na zamieszkujących Stupart Żydów. W mieście pojawia się odezwa „Nie będziesz mieszkać wśród nas!", która

9 J. Adler Posłowie do The Journey, s. 289.

10 Ch. Salomon Leben Oder Theater? Ein autobiographisches Singspiel in 769 Bildern, Köln 1981. W wersji angielskiej Life? or Theatre? An Operetta (Leben? oder Theater? Ein Singspiel, 1941-1943, Viking, New York 1981. Zobacz rozdział Kobiety w niniejszym tomie. 
brzmi w ich uszach jak negatywny odpowiednik boskiego przykazania „Nie zabijaj!”. Rzuca ona ponury cień czy też raczej „własne, straszne światło, przed którym gasły wszystkie inne światła"11. Od pierwszego akapitu powieści oksymoroniczne tropy wizualne przekazują stopniowe zanikanie widzialnej rzeczywistości. Adler przywołuje biblijny ton, by oddać eschatologiczny wymiar nadciągającej katastrofy. Przypomina się werset z Księgi Rodzaju, gdy Bóg oddziela ciemność od światłości: „Niechaj się stanie światłość!' I stała się światłość. Bóg widząc, że światłość jest dobra, oddzielił ją od ciemności. I nazwał Bóg światłość dniem, a ciemność nazwał nocą" (rozdział 1, werset 3-5). Tak więc wycofywanie się światła przed zalewającą miasto „straszną ciemnością" jest odwróceniem pierwszego aktu boskiego stworzenia i zapowiada nadchodzącą apokalipsę.

Eschatologiczny wymiar pierwszego rozdziału osadzony jest również w kategoriach świeckich. „Nie będziesz mieszkał wśród nas!” oznacza anulowanie osiągnięć myśli oświeceniowej, odsłaniając, jak to ujął Zygmunt Bauman, „coraz wyraźniej widoczną ciemną stronę cywilizacji judeochrześcijańskiej [...].To błąd wyobrażać sobie, że cywilizacja i dzikie okrucieństwo są antytezami"12. W Nowoczesności i zagładzie Bauman rozpatruje powiązania między zachodnim pradygmatem myśli racjonalistycznej i czynnikami, które przyczyniły się do eksterminacji europejskich Żydów. Oświecenie przyniosło grupom społecznym, które do tej pory były pozbawione praw politycznych, obietnicę emancypacji, a wielu członków społeczności żydowskich w miastach takich jak Praga, Berlin i Wilno opowiedziało się za Haskalą (żydowskim Oświeceniem). Począwszy od Kartezjusza, myśli oświeceniowej przyświecała wiara $\mathrm{w}$,jasno określone pojęcia”, a więc posługiwała się ona metaforyką światłości rozumu, jasności racjonalnego pojmowania rzeczywistości i światła rozpraszającego ciemność niewiedzy jako najwyższymi wartościami, które mają prowadzić do powszechnego postępu ludzkości. Według Baumana potencjał nowoczesnej cywilizacji okazał się jednak destrukcyjny: wiara w prymat nauki oraz pogoń za efektywnym jej wykorzystaniem spowodowały „zaślepienie” rozumu, jeśli chodzi o wartości moralne: „W systemie, w którym drogi racjonalności i etyki się rozchodzą, największym przegranym jest człowieczeństwo"13. Co oznacza wobec tego dla członków praskiej społeczności 
żydowskiej, którym w większości przyświecał ideał myśli racjonalistycznej, fakt, że w XX wieku ich prawo do istnienia, ich miejsce na ziemi jako istot obdarzonych rozumem, zostaje „zakazane”?

Dewolucji boskiego stworzenia i wygaśnięciu świateł towarzyszy w powieści refren „wszystko było zakazane”: reguły postępowania odwoływane są jedna po drugiej, niczym w negatywnej, polegającej na odejmowaniu grze językowej:

Drogi i ścieżki są zakazane, dni zostały skrócone a noce wydłużone, już nie mówiąc o tym, że noc została zakazana i dzień też został zakazany [...]. Sklepy zostały zakazane [...] muzyka została zakazana, taniec zakazany. Buty zakazane [...]. To co było i to co ma nastąpić zostało zakazane. Nielojalność została zakazana, również rozum został zakazany [...].Życie zostało zakazane, w co trudno uwierzyć, gdyż jakoś nadal się toczy. ${ }^{14}$

Nie wolno nawet używać własnego imienia: „Żadna normalna istota nie musi się zastanawiać nad tym, jak to jest, gdy trzeba się pozbyć własnego imienia"15. Uprzednio prawo przynależności do wspólnoty zapewniały obywatelom pochodzenia żydowskiego wywieszone na drzwiach tabliczki z ich nazwiskami. Lecz tabliczki zostały pozrywane, a ich mieszkańcy skazani na bezimienność i nieistnienie, a jedyny ślad, jaki po nich pozostanie, to jedynie „niezrozumiała zbieranina pozostawionych odpadków”16.

Wycofywaniu się światła towarzyszy odwołanie boskiego słowa, które stworzyło światłość. Tak więc, jeśli język człowieka jest jedynie niedoskonałym odbiciem boskiego słowa, w Adlerowskiej antyksiędze Rodzaju słowa również skazane są na zniknięcie: „Gdyż język już do nas nie należy, umyka nam, brzmi jakoś dziwnie w ustach tych, którzy próbują się nim posługiwać"17.

14 Tamże, s. $24-25$ i s. 31.W studium Die Juden in Deutschland. Von der Aufklärung bis zum Nationalsozialismus (1960) Adler szkicuje historię antysemityzmu niemieckiego od czasów osiedlenia się w średniowieczu pierwszych żydowskich przybyszów. W pracy tej Adler często używa wyrażenia "zostało zakazane”, by opisać proces pozbawiania Żydów praw cywilnych na przestrzeni wieków. Ukazuje w ten sposób historyczną ciągłość między zakazywaniem im praw cywilnych, takich jak przynależność do cechów, posiadanie majątku i uprawianie roli, a prześladowaniami przez reżym hitlerowski, który usankcjonował drastyczne sposoby "zakazywania".

Tamże, s. 20.

Tamże, s. 16 is. 63.

Tamże, s. 9 .... 
Nawet muzyka cichnie: gdy nadchodzi rozkaz konfiskacji instrumentów muzycznych, bohater powieści, Paul, wyrywa struny z lutni swojej siostry Zerliny. Pod koniec pierwszego rozdziału rodzina Lustigów zostaje eksmitowana z mieszkania i wysłana w koszmarną podróż: widzimy, jak powoli schodzą po schodach, snują się po pozbawionym światła mieście, a następnie jadą pociągiem, w świetle chyboczącej się żarówki, która „nie daje światła, jedynie migocze"18.

Wygasanie światła jest równoznaczne z postępującym procesem odbierania Żydom prawa do życia. Sekwencja ta przypomina nieco późniejsze stwierdzenie historyka Zagłady Raula Hilberga, w pracy Zagłada Żydów europejskich, że „misjonarze chrześcijańscy oznajmili Żydom: 'nie wolno wam żyć wśród nas jako Żydzi!' Władcy świeccy stwierdzili następnie: 'Nie wolno wam mieszkać wśród nas!' Hitlerowcy doszli ostatecznie do wniosku, że 'Nie wolno wam żyć!'”19. Narrator powieści Adlera ma podobną refleksję, gdy zwraca się do współmieszkańców Stupartu: „Zastanówcie się dobrze nad tym, jakie prawo do miejsca spoczynku daje wam to, że rzekomo jesteście obdarzeni prawem do istnienia. Zadajcie sobie to pytanie, gdy tak zmuszeni jesteście uciekać, a wszystko co posiadacie zostało wam odebrane"20. Domaganie się przez skazańców prawa do istnienia, ich samozapewnienia, „wiem, że jestem”, są jedynie wyrazem naiwności i próbą pokonania wszechobecnego strachu²1. Gdy gaśnie światło, nie ma niczego, co „zapewniałoby, że istniejecie” i „Błogosławieni niech będą ci, którzy nie wierzą, gdyż teraz wszystko pokryte jest ciemnością"22.

Obrazy w Podróży zieją pustką, są okaleczone, bezforemne i ledwie widoczne. Pochłania je czerń, jak na filmowym negatywie, a postacie przepływają w ciemnościach, jak upiory. Nowatorskie wykorzystanie przez Adlera techniki wizualnej oraz nacechowanego afektywnie języka zdradza wpływ niemieckiej sztuki ekspresjonistycznej, zwłaszcza malarstwa, a szczególnie przypomina prace wykonane w Terezinie przez współwięźniów pisarza, tzw. wielkich malarzy grozy (grossen Maler des Grauens), którzy tworzyli prace

18 Tamże, s. 37.

19 R. Hilberg The Destruction of the European Jews, Yale University Press, New Haven, Conn. 1961), S. 9 . H.G. Adler Podróż, s. 9. Tamże, s.49.

Tamże, s. 61 is. 8. 
oddające rzeczywistość getta, a następnie przekazywali je na zewnątrz, posługując się sztuką jako formą ruchu oporu. Skojarzenie to nie jest przypadkowe, gdyż zainteresowanie pisarza sztuką było dobrze znane: według badaczki zajmującej się Terezinem, Eleny Makarovej, Adler wygłosił w getcie sześć wykładów w ramach „uniwersytetu latającego”, z których dwa były na temat sztuki („Barok i nowoczesność” i „Naturalizm, idealizm i modernizm w sztuce") ${ }^{23}$. Ponadto, w rozdziale zatytułowanym Kultur we wspomnianym powyżej studium o Terezinie, Adler opisuje prace artystów, takich jak Bedřich Fritta, Otto Ungar, Karel Fleischmann i František Petr Kien, choć pomija równie wybitnego członka Zeichenstube, Leo Haasa, jedynego, który ocalał. Natomiast zajmuje się szczegółowo pracami Fritty i podziwia go za próbę zdemaskowania hitlerowskiego projektu „upiększania” Terezina [Verschönerung], który miał na celu zrobienie dobrego wrażenia na członkach Czerwonego Krzyża podczas wizyty zapowiedzianej na 23 czerwca 1944 roku. Próbę tę artysta przypłacił życiem ${ }^{\mathbf{2 4}}$. W rozdziale Kultur Adler dowodzi, że forma malarska oddaje rzeczywistość getta w szczególny sposób, gdyż „rzeczy odsłaniają się oku w całej pełni, wykraczając nawet poza twórczy zamiar artysty”, do czego nie jest zdolny opis historyczny. Jak stwierdził w innym wykładzie Karel Fleischmann, również członek Zeichenstube, „sztuka, która jest wizualnym zapisem ludzkiego doświadczenia, w ostatecznym rozrachunku niesie świadectwo całemu ludzkiemu życiu", stanowisko, pod którym Adler niewątpliwie się podpisywał ${ }^{25}$. Zainteresowanie Adlera sztuką towarzyszyło mu również po wojnie, być może pod wpływem serdecznej przyjaźni pisarza z młodym czeskim malarzem pochodzenia żydowskiego Jehudą Baconem, również byłym więźniem Terezina i Auschwitz, a dziś wybitnym malarzem izraelskim, znanym m.in. z przejmujących przedstawień Zagłady. Bacon znalazł

23 E. Makarova, S. Makarov, V. Kuperman University over the Abyss: The Story behind 520 Lecturers and 2,430 Lectures in KZ Theresienstadt 1942-1944, Verba Publishers Ltd., Jerusalem 2004, s. $325-326$.

24 Bedřich Fritta (urodzony jako Fritz Taussing, 1906-1944) był przed wojną znanym karykaturzystą i grafikiem. Został wywieziony do Terezina w 1941 roku i tam był odpowiedzialny za Wydział Techniczny, którego zadaniem było wykonywanie ilustracji do oficjalnych raportów. Gdy znaleziono jego potajemne prace przedstawiające życie w getcie, był torturowany, a następnie został wysłany do Auschwitz, gdzie został zamordowany.

Karel Fleischmann (1897-1944) był lekarzem, artystą grafikiem, pisarzem i poetą. Został deportowany do Terezina w 1942 roku i przydzielony do opieki nad starszymi więźniami, w tym prawdopodobnie również teściami Adlera. W 1944 dostał się do transportu do Auschwitz, gdzie został zamordowany. 
się w Terezinie jako 13-letni chłopak i to tam po raz pierwszy zainteresował się sztuką. Peter Kien, najprawdopodobniej zaprzyjaźniony z pisarzem w Terezinie, dawał dzieciom lekcje rysunku, a Bacon był jego najpilniejszym uczniem ${ }^{26}$. Jeśli weźmiemy pod uwagę, że Adler zaczął pisać książkę o Terezinie tuż po wojnie, zainteresowanie, jakie okazywał pracom plastycznym, podkreślając znaczenie artystycznej wyobraźni jako formy świadectwa, jest znamienne i raczej nieczęste we wczesnym okresie historiografii Zagłady.

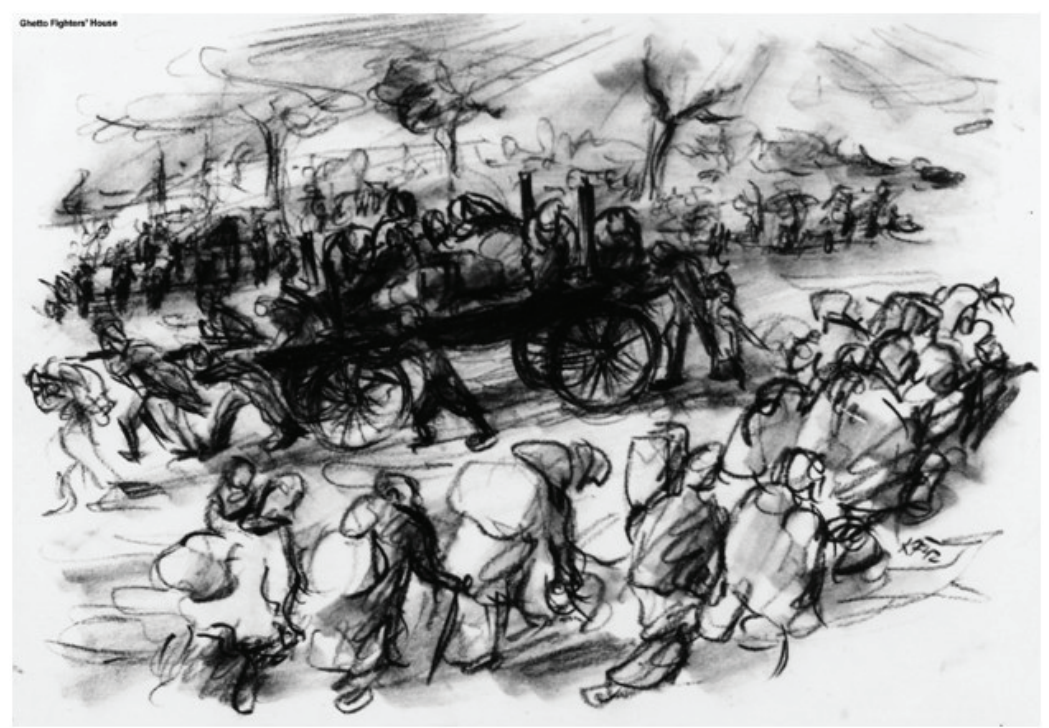

Bedřich Fritta Idq̨cy do Pracy, 1942-1944. Tusz na papierze, $42 \times 52 \mathrm{~cm}$. W zbiorach Beit Theresienstadt (Beit Terezin), Givat Haim-ljud, w Izraelu. Za pozwoleniem Davida Haasa.

Adler przywołuje sceny z życia getta, które są nam dziś znane z prac artystów z Terezina. Przykładem jest obraz Fritty Idacy do pracy (zob. obraz 1), który oddaje codzienną udrękę więźniów zmuszanych do wielogodzinnej ciężkiej pracy fizycznej, w tym przy rozbieraniu murów i wałów ochronnych byłej twierdzy, na miejscu której powstał obóz-getto Terezin. W podobny

26 František Petr Kien (1919-1944) był artystą, pisarzem i poetą, znanym dziś przede wszystkim jako autor libretta skomponowanej przez Wiktora Ulmanna w Terezinie opery Władca Atlanty. Jako więzień Terezina Kien pracował w bloku technicznym, wraz z Bedřichem Frittą, Leo Haasem i Karelem Fleischmannem. Kien został przewieziony do Auschwitz w październiku 1944, gdzie został zamordowany. 
sposób Adler opisuje niewolniczą pracę Paula, bohatera książki, który był zatrudniony w Ruhenthal jako murarz:

Od czasu do czasu cegły są zwoływane i przeliczane. Potem pokazują się karabiny i jakiś głos wrzeszczy: „Ruszać się!” Cegły zaczynają maszerować, bo wyrosły im nogi, jak również ramiona i głowy. Cegły maszerują pomiędzy ścianami, które jeszcze stoją i ścianami, które zostały już zburzone. Te ściany też chcą z nimi iść, nikt nie oponuje, więc coraz więcej cegieł przyłącza się do marszu. ${ }^{27}$

Podobnie jak na obrazie Fritty, ten dziwny opis pracy murarzy jest nie tyle personifikacją cegieł, co ukazaniem odczłowieczenia więźniów, i sprawia wrażenie zamykania się horyzontów świata, w którym nie pozostało już nic ludzkiego.

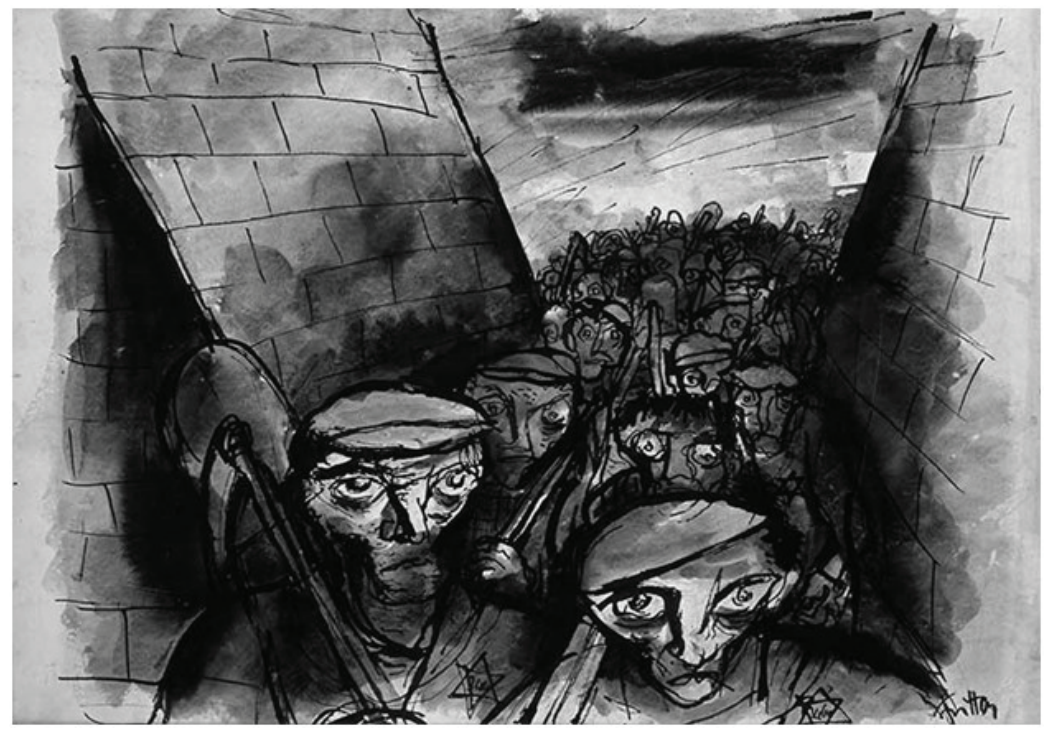

Karel Fleischmann Przyjeżdżający i odjeżdżający, 1942-1944. Rysunek. Za pozwoleniem Beit Lohamei Haghetaot (Ghetto Fighters' House), Zachodnia Galilea, Izrael.

27 H.G. Adler Podróż, s. 45. 
Inna postać w powieści, Leopold Lustig, wcześniej cieszący się poważaniem lekarz, zmuszony jest pracować w grupie wywożącej śmieci, wraz z innymi „bezużytecznymi” starszymi więźniami. Ruhenthal, „miasteczko pełne duchów", wypełnione jest po brzegi odpadami: gruzem, odpadkami jedzenia oraz zwłokami ludzkimi i zwierzęcymi, które należy czym prędzej usunąć. Śmieci ładowane są na stare wozy pogrzebowe, a następnie wrzucane do wielkiego dołu. Wozy „nie są napędzane silnikiem, czy ciągnięte przez zwierzęta, lecz wleczone przez ubrane w szmaty widma, które ledwie powłóczą nogami"28. Leopold, teraz jako jedno z „widm”, przekonuje się, że „Sam [jest] śmieciem, ale takim, któremu nie wolno znaleźć się między stołem a łóżkiem, pomiędzy krzesłem a komodą"29. Te oraz podobne opisy więźniów sprawiają wrażenie, że człowieczeństwo wycieka z ich bezkształtnych ciał. Od czasu do czasu czytelnik jest świadkiem przedziwnej metamorfozy, przywodzącej na myśl apokaliptyczne obrazy Hieronima Boscha: „Zamieniali się w ptasie głowy z nastroszonymi piórami, rozstrzelanymi oczyma i wystającymi, zakrzywionymi dziobami [...]. A teraz w węże, z niekończącymi się ogonami. Widać wystające, zatrute jadem kły" ${ }^{\text {"30 }}$.W innym opisie widzimy „chyboczące się widma, wloką się, obsuwają, pchają do przodu” czy też „ciemne postacie, utrudzone, pełzną przez zgniłą maź"31. Ten ostatni opis przypomina z kolei obraz Karela Fleischmanna, zatytułowany Przyjeżdzajacy i odjeżdżajacy, który przedstawia kolejną, dobrze znaną scenę z życia w Terezinie (zob. obraz 2). Podobnie do szkiców Fritty i Fleischmanna, Adler oddaje wrażenie nieustającego koszmaru za pomocą całej gamy odcieni ciemności: „Było ciągle ciemno, ciemniej niż jest to możliwe. Ta ciemność była tak ciemna, że nie można jej było zobaczyć" 32 .

Kolejna wstrząsająca scena to opis śmierci Zerliny, która przechodzi serię groteskowych przemian, przypominających najbardziej ponure fragmenty baśni braci Grimm³ ${ }^{33}$. Najpierw zamienia się w dziewczynkę pokrytą smołą:

28 Tamże, s. 67.

29 Tamże, s. 84.

30 Tamże, s. 46-47.

31 Tamże, s. 88,. 125.

32 Tamże, s. 211.

33 Scena ta oparta jest na elementach baśni braci Grimm o dziewczynce pokrytej smołą, zatytułowanej Frau Holle, w: The Complete Fairy Tales of the Grimm Brothers, przeł. na angielski Jack Zipes, Bantam Books, New York 1992, s. 96-99. 
"Smoła, smoła, nic tylko smoła, zasmołowane oczy wpatrzone w kruczo-czarną noc i nie widzące nic oprócz smoły", a następnie w białego królika, który jest ścigany, złapany w sidła, ugotowany i zjedzony, , pochłonięty przez nieprzenikniony cień ociężałej nocy" ${ }^{34}$. Na koniec, w finałowym akcie teatralnej makabreski, ciało Zerliny znika w czeluściach pieca krematoryjnego: „Na jasno oświetlonej scenie z lewa i prawa otwierają się drzwi w kolorze mosiądzu... czarno-brązowa kurtyna zostaje zaciągnięta... Koniec opery, porzucona publiczność... wszyscy zapomnieli o epizodzie z królikiem"35.

Pozostali „zaginieni”, którzy nazywani są teraz „widmami”, wiezieni są pociągiem "przez noc i mgłę" do stacji docelowej" ${ }^{36}$.Zanim jednak wejdą do wagonu, błagają miejscowego reportera, by udokumentował ich istnienie: „Zaklinamy, zrób nam zdjęcie! Co z nas pozostanie, jeśli nikt nie dostarczy dowodów, że jesteśmy?... Istniejemy jedynie, jeśli ktoś zrobi nam zdjęcie! Nawet jeśli będzie podwójnie naświetlone!". Dziennikarz, dumny z posiadania aparatu fotograficznego, ostatniego krzyku mody epoki reprodukcji mechanicznej, nie ulega ich prośbom ${ }^{37}$. W przeciwieństwie do dziennikarza, głuchego na błagania „widm”, Paul, przyszły kronikarz obozów, podejmuje się zadania, by upamiętnić scenę widmowego pociągu, wiozącego „zaginionych" w noc zapomnienia.

Nadchodzi moment wyzwolenia, lecz ciemności długo jeszcze pokrywają krajobraz, jak gdyby wolność zwlekała z nadejściem. W końcu na horyzoncie pojawia się światło: „Promienie przedarły się przez chmury, zniknęły, a następnie wytrysnęły spoza pióropusza chmur. Cała kraina skąpana jest w złocie, słońce odniosło zwycięstwo". Paul zmierza w stronę „zlanego słońcem dnia", lecz nie udaje mu się wkroczyć do świetlanego kręgu, gdyż tak jak Józef, niesie ze sobą cynową puszkę pełną wspomnień, zebranych $\mathrm{w}$ „przepastnym miejscu, którego wzrok nigdy nie przeniknie” ${ }^{\text {38 }}$. Ta pieczołowicie przechowywana kolekcja obrazów różni się zasadniczo od pobliskiej wystawy w nowo utworzonym Muzeum Technologii, która zawiera gabloty

34

Tamże, s. $168,173$.

Tamże, s. 196.

Wyrażenie "noc i mgła” jest najprawdopodobniej celowe i odnosi się do wydanego 7 grudnia 1941 roku przez Hitlera ściśle tajnego dekretu, znanego dziś w historii jako akcja "Noc i mgła” (Nacht und Nebel). Taki tytuł nosi również jeden z pierwszych filmów dokumentalnych o obozach hitlerowskich, w reżyserii Alaina Resnais'a (1955).

7 H.G. Adler Podróż, s. 110-112.

Tamże, s. 223 , s. 260. 
z butami, włosami i walizkami. Eksponaty są symbolem budzącego grozę zwycięstwa myśli oświeceniowej, której kulminacją stało się zredukowanie istot ludzkich do statusu śmieci. Przed Paulem stoi zadanie odkupienia tego barbarzyńskiego wykwitu cywilizacji. Motyw odkupienia zasugerowany jest w samej metaforze śmietniska: jak wyjaśnia tłumacz powieści Peter Filkins, Adler nieprzypadkowo używa słowa der Abfall [śmietnisko]; w języku niemieckim oznacza ono również biblijny „upadek człowieka”, po raz kolejny przywodząc na myśl motyw z Księgi Rodzaju. Powtórzmy, że w pracy Theresienstadt zadaniem odkupienia przeszłości i przywrócenia pamięci „widmom" Adler obarczył malarzy z terezińskiej Zeichenstube, co większość z nich przypłaciła życiem. Po zakończeniu wojny wykonane potajemnie obrazy i rysunki zostały użyte jako materiały dowodowe w procesie zbrodniarzy hitlerowskich w Norymberdze. Wykorzystywano je również wielokrotnie w celu zdemaskowania misternie stworzonego przez Niemców oszustwa, mającego zmylić inspektorów Czerwonego Krzyża. Głównym elementem propagandowej machiny miał być film dokumentalny zatytułowany Theresienstadt. Ein Dokumentarfilm aus dem jüdischen Siedlungsgebiet [Terezin: Film dokumentalny z terenu osiedlania Żydów], wyreżyserowany przez jednego z więźniów, czeskiego artystę i filmowca pochodzenia żydowskiego Kurta Gerrona. Film znany jest jako Der Führer schenkt den Juden eine Stadt [Führer darowuje Żydom miasto]. W książce The Artists of Terezin Gerald Green potwierdza, że „sztuka wykorzystywana była do demaskowania hitlerowskiego fałszerstwa w Terezinie" ${ }^{\prime 39}$.

Dodajmy, że w wyreżyserowanym w 2006 roku przez fundację Simona Wiesenthala filmie edukacyjnym o getcie w Terezinie, zatytułowanym Theresienstadt, obrazy Haasa, Fritty i Fleischmanna zostały wykorzystane jako materiał dokumentalny, przedstawiający prawdę o życiu obozu-getta. W ramach kontrastu fragmenty filmu reżyserowanego przez Gerrona zostały załączone, by podkreślić zwodniczy charakter reżimu hitlerowskiego. Niemniej jednak nazwiska malarzy nie są wymienione ani razu w filmie fundacji Wiesenthala i nie pojawia się komentarz dotyczący tego szczególnego odwrócenia ról między dokumentem filmowym a pracami plastycznymi, jeśli chodzi o autentyczne przedstawianie rzeczywistości.

We wstępie do Podróży tłumacz Peter Filkins opisuje literacką wizję Adlera jako uwidacznianie tego, co niewidoczne (making visible the invisible), ekshumowanie z cynowego pudełka treści pogrzebanych pod grubą warstwą 
zapomnienia $^{40}$. Filkins określa styl Adlera jako modernistyczny, porównując go do dzieła „chłodnej ręki artysty” Jamesa Joyce’a (z Portretu artysty z czasów młodości), który, jak obojętny dziejom świata Bóg deistów, przygląda się okrucieństwom historii i spokojnie obcina sobie paznokcie ${ }^{41}$. Powyżej zaproponowałam porównanie z nieco innym słynnym modernistycznym obrazem, a mianowicie z pracą Paula Klee Angelus Novus. W interpretacji Benjamina Anioł, przedstawiony z otwartymi ustami i skrzydłami rozpostartymi zawieruchą dziejów, symbolizuje postać badacza historii, którego zadaniem jest pozbieranie rozproszonych kawałków i złożenie ich w całość upamiętniającą tych, których historia zmiotła na śmietnisko. Kronikarz podejmuje się opisania katastrofy, gdyż ma nadzieję na odkupienie historii naznaczonej barbarzyństwem. Jak twierdzi Adler, w Terezinie zadania tego podjęła się grupa artystów, „grossen Maler des Grauens”. Jej prace stały się symbolem autentycznego świadectwa, mającego moc zdemaskowania zakłamanej wersji historii. Powieść Adlera, jakże odmienna od świadectw, które pojawiły się w pierwszych latach po wojnie, stanowi ich literacki odpowiednik.

\section{Zakazana reprezentacja i wyobraźnia empatyczna}

WTezie IV Benjamin stwierdza: „przeszłość można uchwycić tylko jako obraz, który w chwili swej rozpoznawalności właśnie rozbłyska na wieczne pożegnanie"42 . Benjamin, kolekcjoner cytatów, zafascynowany konwencją aforyzmu - oraz czerpiący inspirację z obrazu Paula Klee - określał warsztat myśliciela, zarówno krytyka kultury, jak i badacza historii, jako zapisywanie myśli-obrazów (Geschichte Denkbilder). Jak dodaje w Tezie VI, zakrzepła w obrazie myśl oddaje wagę momentu historycznego, „rozsadzając kontinuum historii"43. W jednym z listów do Maxa Horkheimera Benjamin stwierdził, że „historia to nie tylko nauka, ale również forma pamięci. Pamięć może połączyć w całość to, co niekompletne (szczęście) i spowodować, że to co całe, stanie się niekompletne" ${ }^{44}$. Pytanie właśnie o „formę pamięci” pojawia

40 P. Filkins wstęp do Podróży, s. XIX.

41 Tamże, s. XX.

Tamże, s. 422. 
się w powieściach, które Adler napisał na wiele lat przed tym, gdy zaczną się toczyć debaty akademickie na temat granic przedstawialności Zagłady. Jako pisarz, socjolog i badacz historii, Adler poszukuje nowych sposobów jej przedstawiania, wbrew tradycyjnym paradygmatom. Benjamin skrytykował je w Tezach, gdyż przyczyniły się one do przemiany historii w katastroficzny stos gruzów (czy też w Adlerowskie wielkie śmietnisko). Benjamin stwierdza: „Tylko temu dziejopisowi przysługuje dar rozjarzania w minionym iskry nadziei, który jest tym pragnieniem przeniknięty: umarli także nie będą bezpieczni przed wrogiem, kiedy zwycięży. A ten wróg nie przestał zwyciężać”45. Według zarówno Benjamina, jak i Adlera źródłem pamięci historycznej jest nie tylko przeszłość, ale i nadzieja na przyszłość. Wizja historii odarta z tej nadziei, jak obawia się bohater Podróży, sprawia, że „to co zostało zniszczone nigdy nie istniało, a to co istniało na próżno, nigdy nie było naprawdę"46 Wyrażenie „iskry nadziei” w cytacie z Tez zaczerpnięte jest z kabalistycznej legendy shevirat ha kelim (rozbicie naczynia zawierającego boskie światło), która zapowiada zbawienie ludzkości, gdy skorupy naczynia i okruchy światła zostaną zebrane i ponownie połączone w całość. Mimo ciemności pokrywających pełne gruzów krajobrazy, do których rzadko przedziera się promień światła, Podróż kończy się spojrzeniem w przyszłość, nawet jeśli jest ono niepewne i zabarwione egzystencjalną nutą: „Bezdomność nie musi prowadzić do nicości... Rozpaczać należy ku czemuś a nie nad czymś"47. W ostatniej scenie powieści Paul wsiada do pociągu, by udać się w dalszą wędrówkę, lecz w międzyczasie zmieniło się znaczenie słowa „podróż”. Nie będzie to, jak poprzednio, zejście do piekieł, lecz wyprawa w jasno wytyczonym kierunku, ku przyszłości: „Rzeczywiście, odkąd otworzyliśmy oczy, odczuwamy nie tylko cierpienie, ale również życie"48. Tym razem Paul wybiera się w podróż w ciągu dnia, a nie jak poprzednio, w środku nocy, niesie walizkę i macha ręką do zebranego tłumu, który życzy mu udanej podróży. Jego ostatnie słowa to „pokonaliśmy w końcu śmieci i gruz!"49. Spieszy mu się, prawdopodobnie dlatego, że ma wiele do zrobienia.

W. Benjamin Tezy, s. 416.

H.G. Adler Podróż, s. 81.

Tamże, s. 280-281.

Tamże, s. 5 .

Tamże, s. 284. 
W zakończeniu powieści Adler pozostawia czytelnika z pewną dozą wiary w przyszłość, połączoną z przesłaniem o konieczności niesienia świadectwa. Choć formuła ta sama w sobie jest konwencjonalna, dywagacje pisarza, w jaki sposób należy podjąć się zadania, poważnie ją komplikują. Adler zdaje sobie sprawę, że poszukiwanie odpowiedniej formy upamiętnienia musi być połączone z pytaniem o sposoby przedstawiania historii, jako że historia również została „zakazana" w hitlerowskich obozach zagłady. W wywiadzie dla telewizji niemieckiej, przeprowadzonym w 1986 roku (na dwa lata przed śmiercią pisarza), Adler wspomina, że już w obozie przyrzekł sobie: „Jeśli przeżyję, chcę to wszystko przedstawić i to na dwa różne sposoby. Chcę zbadać, co się stało w sposób naukowy, czyli z pełnym dystansem, ale również stworzyć portret literacki.Udało mi się dokonać jednego i drugiego, co nie jest wielkim osiągnięciem, ale przynajmniej daje jakieś uzasadnienie temu, że udało mi się przeżyć" ${ }^{\circ 0}$. Odczytuję więc wielowymiarowy, całościowy projekt Adlera (który sam określił on jako Gesamtkunstwerk), składający się z prac zarówno naukowych, jak i literackich, jako próbę przewartościowania problematyki obrazu w odniesieniu do przedstawiania historii, zwłaszcza historii traumatycznej. Jeśli niesienie świadectwa musi uwzględniać spowodowany Zagładą kryzys paradygmatu przedstawialności, musi się to odbyć niejako z samego wnętrza obrazu, z jego ontologicznego podłoża. Być może jest to najważniejsze, choć również najbardziej skomplikowane przesłanie Adlerowskiej koncepcji opisywania przeszłości. Pisarz zdaje się przytakiwać wypowiedziom Karela Fleischmanna, lekarza-artysty, które najprawdopodobniej zasłyszał podczas wykładów w Terezinie: „Zarówno naukowiec jak i artysta mają ten sam cel - poszukiwanie prawdy"s1. Dążenie do odwrócenia wyroku odbierającego Żydom prawa do życia oraz dostarczenie dowodów na istnienie ofiar reżimu hitlerowskiego motywowały zarówno twórczość artystów z Terezina, jak i Adlerowski projekt upamiętnienia.

Wielowymiarowość Adlerowskiej syntezy nieprzystających - wydawałoby się - dyskursów, naukowego i artystycznego, łączy się więc z pytaniem, postawionym po raz pierwszy przez Adorna, o kryzys przedstawialności „po Auschwitz". Wiele lat później wyzwania podjął się m.in. francuski filozof Jean-Luc Nancy w pracy La représentation interdite [Zakazana reprezentacja]. Według Nancy'ego problem reprezentacji po Shoah nie polega na niemożności

50 J. Adler, Good Against Evil? H. G. Adler, T. W. Adorno and the Representation of the Holocaust w: Social Theory After the Holocaust, red. R. Fine, Liverpool 2000, całość dzieła s. 255-289; S. 258. 
przedstawienia okrucieństw czy wyartykułowania traumatycznych treści ${ }^{\mathbf{5 2}}$. Bądź co bądź pojawiło się w międzyczasie wiele przedstawień Zagłady, które się na to poważyły. Przeciwnie, „reprezentacja Shoah jest nie tylko możliwa i dozwolona, ale w rzeczywistości jest konieczna i niezbędna"53. Sformułowanie „zakazana reprezentacja” nie odnosi się więc do radykalnego braku środków wyrazu czy do religijnego zakazu ikonoklazmu, a więc niemożności obrazowania grozy lub świętości, do której reprezentacja po prostu się nie odnosi. Zamiast tego należy postawić pytanie, w jaki sposób Shoah wpłynęło na zachodni paradygmat myślenia w kategoriach reprezentacji, czyli „co stało się w Auschwitz z samą reprezentacją?"54. Nancy postuluje, że Shoah spowodowało ostateczne załamanie się paradygmatu przedstawialności, czyli wykształconego w myśli zachodniej sposobu doświadczania rzeczywistości. Nie chodzi więc jedynie o poezję czy sztukę, które okazały się sprzymierzone z kulturą barbarzyństwa, ale również całego modelu epistemologicznego. Porządek ten zakłada istnienie idei i pojęć, które są pojmowane rozumem, poznawalne same w sobie, natomiast pozostają nieobecne w sferze percepcji i poznania zmysłowego. Podstawą metafizycznej idei prawdy jest nieobecność, jako że metafizyczna prawda objawia się jedynie w sposób negatywny, wycofując się ze sfery przedstawialności i uobecnienia. Tak więc nieobecność jest podstawowym warunkiem umożliwiajaccym poznanie prawdy: „Bóg [...] swoją prawdę ujawnia wyłącznie poprzez wycofanie swojej obecności - obecności, której sensem jest absens" ${ }^{55}$.W tak pojętej rzeczywistości, to, co określamy jako „reprezentacja”, jest więc swego rodzaju uobecnieniem w domenie zmysłów owej konstytutywnej, pojmowalnej jedynie przez rozum nieobecności. Obraz, czyli to, co pojawia się i jest przedstawione jako dostępne zmysłom, okazuje się „wtórne, imitatorskie, i tym samym nieistotne, pochodne i nieożywione”56. Nancy wskazuje tu na zasadniczą więź między pojęciem obrazoburstwa w judaizmie i greckim rozróżnieniem między kopią a symulakrum, z którego wywodzi się nieufność do obrazu w myśli zachodniej. Wywodzące się z tej tradycji

52 Używam w tym wypadku terminu "Shoah", zgodnie z terminologią preferowaną przez myślicieli francuskich.

53 J.-L. Nancy Zakazana reprezentacja, przeł. A. Dziadek, "Teksty Drugie” 2004 nr 5, s. 115.

54 Tamże, s 120.

55 Tamże, s. 118. Wyraz absens ma oddawać homonimiczną grę słów: wycofywanie znaczenia czy sensu (ab-sens) oraz nieobecność (absence).

56 Tamże, s. 118. 
pojęcie estetyki zakłada „przedstawienie nieobecności otwartej w samej danej zmysłowej dzieła zwanego ‘dziełem sztuki'”s?.

Nancy twierdzi, że ideologia nazistowska, opierająca się na „woli uobecnienia tego, co jest poza obecnością [...] woli reprezentacji bez reszty, bez jakichkolwiek wydrążeń", doprowadziła do załamania się zachodniego porządku reprezentacji ${ }^{58}$. Choć przedstawialność odgrywała kluczową rolę w wykuwaniu nazistowskiej ideologii, jej dążeniem było osiągnięcie pełni reprezentacji, przedstawienie prawdy unaocznionej, in praesentia, czyli jako całkowitego, immanentnego i bezpośredniego uobecnienia, bez jakiejkolwiek pozostałości. Nadreprezentacja jest więc postacią bałwochwalstwa, które odznacza się tym, że idea musi stać się w pełni widzialna, unaoczniona w jasno oświetlonym rejonie pozbawionym światłocienia. W ideologii narodowego socjalizmu absolut przedstawialności zostaje uosobiony jako idealne aryjskie ciało. Aryjski archetyp z kolei pojawia się w postaci doskonałej jako ciało przywódcy (ein Führer), którego żywe słowo jest równoznaczne z nadrzędnym prawem ${ }^{59}$. W obrębie nazistowskiego systemu reprezentacji, który nie dopuszcza nieprzedstawialności, przedmiot czy idea „spełnia się całkowicie w manifestowanej rzeczywistości”. Dla Schutzstaffel (esesmanów), którzy ukazują się więźniom w splendorze czarnych mundurów z emblematem trupiej główki na czapce, rzeczywistość ta „musi się odnosić do wzorcowego obrazu czarnego słońca, które stanowi odbicie śmierci w ich oczach"60. Stąd obrazem tego modelu jest swastyka - starożytny symbol słońca. W tak pojętym rozumieniu rzeczywistości Żydzi są zaprzeczeniem nadreprezentacji, zagrożeniem porządku pełnego uobecnienia; zadaniem SS jest więc ich wyeliminowanie. Żydzi nie mogą w tym uniwersum zaistnieć, gdyż są pozbawieni możliwości reprezentowania czy zaznaczenia swego istnienia w jakikolwiek sposób. Nancy przytacza tu słowa więzionego w Auschwitz austriackiego pisarza Jeana Amèry'ego: „Można było być zagłodzonym, zmęczonym, chorym. Ale mówienie, że się jest, nie miało żadnego sensu". Tak więc nawet śmierć ofiar, czyli ich „niezawłaszczalna własność istnienia” (w ujęciu heideggerowskim) staje się nieprzedstawialna ${ }^{61}$. W mniemaniu Nancy'ego jedynym logicz-

\footnotetext{
57 Tamże, s. 119.

58 Tamże, s. 128.

59 Tamże, s. 125.

60 Tamże, s. 128.

61 Tamże, s. 129-130.
} 
nym znaczeniem stwierdzenia, że eksterminacji nie da się przedstawić, jest fakt, że wszelkie dostępne zmysłom figury i formy, takie jak np. obrazy Olère (poniekąd usankcjonowane statusem artysty jako byłego więźnia Auschwitz i członka Sonderkommando) nie są reprezentacją, a jedynie symboliczną formą upamiętnienia. Podobnie tzw. antypomniki w wykonaniu artystów takich jak Jochen Gerz, Esther Shalev-Gerz i Horst Hoheisel, które pojawiły się w Niemczech w latach 8o., wyrażają jedynie na przeciwstawnym biegunie poczucie winy i próbę zmierzenia się z odpowiedzialnością za zbrodnie. Nancy dochodzi do wniosku, że upamiętnienie Shoah, które jest konieczne, musi wyjść od przedstawień i środków wyrazu, które odsłaniają unicestwienie czy też „egzekucję" (w podwójnym tego słowa znaczeniu) porządku reprezentacji, a jego ulubionym przykładem jest Shoah Claude’a Lanzmanna, film, który, dotykając śmierci, wysuwa jej (nie)reprezentowalność na plan pierwszy.

Adorno zawyrokował, że „wszelka kultura po Oświęcimiu, włącznie z jej najwnikliwszą krytyką, jest śmietniskiem"62. Adler ukazał natomiast, że jeśli europejska kultura to jedno wielkie śmietnisko, kryzys ten dotyczy głównie faktu, że ludzie zostali sprowadzeni do statusu cuchnących odpadków. Tę głęboko humanistyczną tezę obrazuje los powieściowego Leopolda Lustiga, który dosłownie staje się „śmieciem”. Jeśli cały obszar przedstawialności zapada się w „Auschwitz”, zamienia w wysypisko śmieci, a śmierć jest pozbawiona metafizycznego wymiaru (co według Adorna jest „gorsze niż śmierć"), musimy poszukiwać koncepcji obrazu, który jest w stanie rozbić nadreprezentacyjny porządek w sercu hitlerowskiego Weltanshauung, a tym samym zaświadczyć o śmierci nieprzedstawialnych „widm”. Posługując się metaforyką światła i ciemności, Adler niejako wchodzi w głąb obrazu, drąży go od środka, zmagając się z pytaniem o możliwość reprezentacji po Zagładzie z wnętrza ciemnej otchłani, z której wycofało się słowo i światło.

W obrębie ideologii, w której Żydom zakazano prawa do „jestem”, reprezentacja jest zakazana, lecz narrator Podróży przypomina sobie, że ładowane do pociągu „widma” wołają do obojętnego na ich prośby dziennikarza: „Tylko to co zakazane może nas uratować!", czyli uchronić ich przed tym, co jest gorsze niź śmierć. Odczytuję znaczenie tego enigmatycznego zawołania jako stwierdzenie, że reprezentacja, która najlepiej oddaje doświadczenie „zaginionych”, to właśnie reprezentacja „zakazana”, wywodząca się z czeluści niebytu, w którą wtrąceni zostali bohaterzy powieści, w sensie podobnym, jaki nadał temu wyrażeniu Nancy. Niemniej jednak dla Adlera imperatyw ten jest

62 Th.W. Adorno Dialektyka negatywna, s. 515. 
wyraźnie nacechowany etycznie, gdyż niesie ze sobą nakaz pamięci o tych, których samo istnienie zostało zakazane, takich jak członkowie jego rodziny czy artyści z Terezina. Tak więc całokształt Adlerowskiego Gesamtkunstwerk, a w szczególności dwie pierwsze powieści, które w tak niezwykły sposób oddają doświadczenie grozy i utraty, odsłania etyczny wymiar ontologicznego wywodu Nancy'ego: bałwochwalstwo hitlerowskiej nadreprezentacji było ściśle powiązane z próbą zanegowania prawa ich ofiar do życia, ich niezbywalnego ,jestem”.

Twierdzę, że w prozie Adlera ten etyczno-ontologiczny postulat połączony jest z apologią empatycznej wyobraźni. Adler uruchamia potencjał wyobraźni wobec kryzysu paradygmatu przedstawialności, a zakończenia jego dwóch wczesnych powieści sugerują, że pisarz żywi nadzieję na stworzenie nowych możliwości wyrażania traumatycznych treści. Czyni to, posługując się poetyckimi środkami wyrazu, a zwłaszcza dialektyczną metaforyką światła i ciemności. Prekursorska refleksja Adlera na temat przedstawialności „po Auschwitz" w znacznym stopniu została zastopowana potępiającym estetyzującą ekspresję wyrokiem Adorna. Niemniej jednak na wiele lat przed tym, jak rozpętały się polemiki na temat granic przedstawialności czy kryzysu reprezentacji po Zagładzie, Adler przeczuwał, że stawką w upamiętnianiu tego, co się stało, jest konieczność przemyślenia, czym jest obraz i na czym polega przedstawialność. Jest to niezbędne, jeśli - jako rasa ludzka - chcemy trwać w założeniu, że każdy z nas ma prawo do istnienia. W wyniku Zagłady myśl zachodnia została zmuszona do zmierzenia się z faktem, że prawo to może zostać w każdej chwili zakwestionowane. Stawką Adlerowskich eksperymentów z metaforyką światła i ciemności jest więc coś więcej niż poszukiwanie nowych środków wyrazu. Jeśli całkowite wyeliminowanie Żydów było warunkiem dopełnienia nazistowskiego porządku nadreprezentacji, kwestia reprezentacji i przedstawialności po Zagładzie zahacza o porządek etyczny: nasze prawo do życia zależy od tego, w jaki sposób stajemy się „widzialni" czy też ze sfery przedstawialności wykluczeni. To, czy inni są w stanie nas w sferze widzialności uznać i rozpoznać, czyli nasze „bycie” w świecie, a więc i sens świata (jak i jego ab-sens), uzależnione jest od naszego umiejscowienia w danym porządku reprezentacyjnym. Błąkające się wśród nocy zapomnienia „widma” nigdy by nie zaistniały, gdyby nie zachował się czarny obraz, ślad niedostrzegalny gołym okiem, przypadkowo uchwycony na negatywie kliszy i podwójnie prześwietlony. W powieściach Adlera refleksja natury ontologicznej, zakładająca prymat istnienia, jest więc nacechowana etyczną świadomością, że życie jest darem, a moc, która go ochrania przed 
czeluścią niebytu, przed pochłonięciem przez zachodni porządek, który uległ nadreprezentacyjnej metastazie w postaci nazizmu, to m.in. moc empatycznej wyobraźni.

\section{Abstract}

\section{Dorota Głowacka}

UNIVERSITY OF KING'S COLLEGE (CANADA)

Archive and Image: Fragments of a traumatic history according to H. G. Adler

Głowacka's article presents the writer and Holocaust survivor H. G. Adler, author of the first monograph on Theresienstadt concentration camp. The focus is on the early novels Panorama [Panorama] and Podróż [The Journey] - two fictional accounts of the writer's experience at the Nazi camps to which he and his family were deported. Głowacka reads these novels through Walter Benjamin's conceptualization of history as well as JeanLuc Nancy's reflections on the representability of the Holocaust. She compares Adler's idiosyncratic use of visual representation to the painterly techniques of artists such as Fritta, Kien and Fleischmann, Adler's fellow inmates at Theresienstadt.

\section{Keywords}

Holocaust, representability, concept of history, visual art 